\title{
PENGARUH EMPATI EMOSIONAL TERHADAP PERILAKU PROSOSIAL YANG DIMODERASI OLEH JENIS KELAMIN PADA MAHASISWA
}

\author{
Azmi Nisrina Umayah*, Amarina Ariyanto, \& Whinda Yustisia \\ Fakultas Psikologi, Universitas Indonesia, Depok \\ *Email: azminisrina@gmail.com
}

\begin{abstract}
Abstrak
Penelitian ini dilakukan untuk mengetahui apakah terdapat pengaruh empati emosional terhadap perilaku prososial yang dimoderasi oleh jenis kelamin pada mahasiswa. Empati emosional diartikan sebagai dorongan secara otomatis dan tanpa disadari untuk merespon keadaan emosi orang lain dan perilaku prososial diartikan sebagai tindakan yang dilakukan individu untuk membantu orang lain. Empati secara emosional diinduksi dengan cara memberikan sebuah video yang dapat membuat empati seseorang menjadi meningkat atau bahkan netral. Instrumen yang digunakan untuk mengukur empati emosional dengan menggunakan Positive Affect and Negative Affect Scale (PANAS) yang dikembangkan oleh Watson, Clark, \& Tellegen (1988). Pengukuran perilaku prososial dilakukan dengan cara melihat dari jumlah donasi yang diberikan oleh partisipan. Responden penelitian ini merupakan 126 mahasiswa aktif S1 Universitas Indonesia yang terbagi atas laki-laki dan perempuan, dengan kriteria usia 18-25 tahun. Penelitian ini merupakan penelitian eksperimen laboratorium dengan menggunakan desain faktorial 2 (empati: netral vs empati) $X 2$ (jenis kelamin: laki-laki vs perempuan) between subject design. Hasil dari penelitian ini menunjukkan bahwa terdapat pengaruh yang cukup signifikan antara empati emosional terhadap perilaku prososial, namun pengaruh jenis kelamin sebagai moderator terhadap perilaku prososial tidak memiliki efek yang signifikan, namun pada penelitian ini ditemukan variabel lain yang dapat mempengaruhi perilaku prososial pada individu.
\end{abstract}

Kata kunci: empati emosional, jenis kelamin, perilaku prososial

\begin{abstract}
This study was conducted to examine whether emotional empathy could predict prosocial behavior if it's moderated by gender among college students. Emotional empathy defined as automatically and unconsciously impulse that responds to the emotions of others and prosocial behavior defined as an action that individuals do to help others. Emotional empathy induced with a provided video which can increase someone's empathy or the contrary neutralized empathy. Emotional empathy were measured by Positive Affect and Negative Affect Scale (PANAS). Prosocial behavior were measured by looking at the amount of donation given by the participants. The respondents of 126 undergraduate student from Universitas Indonesia (18-25 years) participated in this study. This study/research is an laboratory experimental study with $2 \times 2$ factorial design, between subject design. The result shown there was a significant affect between emotional empathy with prosocial behavior. However, result shown there were no gender differences as the moderator to prosocial behavior. Study found there is another variable influenced individual prosocial behavior.
\end{abstract}

Keywords: Empathy; emotional empathy; gender; prosocial behavior 


\section{Pendahuluan}

Manusia merupakan makhluk sosial yang diciptakan untuk hidup berdampingan dengan manusia lainnya. Untuk dapat hidup berdampingan, individu dapat saling mendukung satu sama lain misalnya dengan saling memberikan pertolongan. Bantuan sebagai tindakan prososial memiliki beragam bentuk diantaranya yaitu sharing (membagi), cooperative (kerjasama), donating (menyumbang), helping (menolong), honesty (kejujuran), dan generosity (kedermawanan) (Eisenberg \& Mussen, 1989). Beberapa penelitian menyebutkan bahwa faktor seseorang dalam memberikan pertolongan berdasarkan empati yang dimiliki tiap individu, namun empati yang dimiliki setiap individu pun berbeda tergantung dengan jenis kelamin maupun motivasi yang dimiliki. Apa sebenarnya yang menyebabkan individu mau untuk menolong?

Perilaku prososial dapat didefinisikan secara singkat sebagai tindakan yang dilakukan oleh individu untuk membantu orang lain tanpa mengharapkan manfaat atau imbalan untuk dirinya sendiri (Baron, Branscombe \& Byrne, 2008). Terdapat dua kategori yang termasuk kedalam perilaku prososial menurut Dovidio dkk., (dalam Schroeder \& Graziano, 2015) yang pertama adalah perilaku menolong (helping behavior) sebagai tindakan yang memberikan keuntungan dengan tujuan meningkatkan kesejahteraan hidup orang yang memberikan pertolongan. Kedua yaitu altruism yang merupakan perilaku memberikan bantuan tanpa mengharapkan keuntungan bagi diri penolong atas tindakannya. Tindakan prososial dapat muncul jika dilandasi oleh dua faktor utama yaitu adanya faktor internal dan faktor eksternal (Baron \& Byrne, 1994). Faktor internal meliputi mood dan helping serta empathy-altruism hypothesis. Faktor ini menunjukkan pentingnya suasana hati dan rasa empati dalam mendorong seseorang untuk berperilaku prososial. Sementara faktor eksternal meliputi role model. Adanya role model ini individu melihat bahwa ketika orang lain melakukan suatu tindakan prososial, maka hal tersebut akan menjadi dorongan bagi dirinya untuk berperilaku prososial. Diantara berbagai faktor pendorong perilaku prososial tersebut, salah satu faktor yang paling banyak diteliti adalah empati yang dikembangkan berdasarkan hipotesis empathy-altruism (Cialdini, Brown, Lewis, Luce, \& Neuberg, 1997). Hipotesis ini menjelaskan bahwa perasaan empati terhadap orang lain menghasilkan motivasi altruistik untuk meningkatkan kesejahteraan orang tersebut (Batson, 1991). Secara konsisten empati mendorong seseorang untuk memunculkan perilaku prososial (Aknin, Dunn, \& Norton, 2012).

Sze, Gyurak, Goodkind dan Levenson (2016) melakukan sebuah studi yang melihat pengaruh empati emosional terhadap perilaku menolong. Empati emosional merupakan salah satu dimensi empati selain empati kognitif (Davis, 1983). Empati emosional dapat diartikan sebagai sebuah reaksi serta dorongan emosional yang ditunjukkan terhadap orang lain yang sedang berada dalam keadaan buruk. Empati emosional yang disebut juga dengan empati afektif merupakan keadaan subjektif akibat dari adanya emosi yang ditularkan oleh orang lain. Empati emosional merupakan dorongan secara otomatis dan tanpa disadari untuk merespon keadaan emosi orang lain (Rogers, Dziobek, Hassenstab, Wolf, \& Convit, 2007). Komponen emosional meliputi perasaan simpatik dan rasa kepedulian kepada orang lain yang berada dalam kondisi kesusahan atau tidak beruntung (empathic concern), respon tersebut juga mungkin dimunculkan untuk menghadapi situasi personal yang tidak nyaman atau perasaan cemas yang ada pada diri sendiri (personal distress) (Rogers dkk., 2007). Sementara itu, empati kognitif merupakan dorongan secara sadar untuk mengenali secara akurat dan memahami keadaan emosional orang lain (Rogers dkk., 2007). Komponen kognitif adalah kemampuan individu untuk menempatkan atau membayangkan (fantasy) dirinya menjadi orang ketiga dalam situasi di mana ia bisa mengambil 
sudut pandang (perspective taking) yang dipunyai orang lain dan dirinya sendiri (Rogers dkk. 2007).

Penelitian Sze, dkk. (2016) melihat pengaruh empati emosional terhadap perilaku prososial dengan cara pemberian film dengan tema "uplifting" dan "distressing". Diketahui bahwa empati yang tinggi dapat memunculkan perilaku prososial tinggi pula dibandingkan dengan individu yang memiliki empati yang rendah. Peningkatan empati dengan pemberian film dengan tema "uplifting" juga terbukti dapat meningkatkan perilaku donasi pada diri individu. Penelitian lain juga dapat dilihat pada studi yang dilakukan oleh Stürmer, Synder, Kropp dan Siem (2006) yang melibatkan variabel identitas kelompok (ingroup atau outgroup) sebagai moderator. Hasilnya sesuai prediksi, bahwa empati dan intensi membantu memiliki hubungan yang signifikan ketika yang membantu adalah individu yang berasal dari ingroup bukan outgroup. Selain itu, dengan metode berbeda, yaitu eksperimental, pengaruh empati terhadap perilaku prososial ditemukan dalam penelitian yang dilakukan oleh Greitemeyer dan Osswald (2010). Hasilnya menunjukkan bahwa partisipan dengan kelompok yang diberikan video prososial terhadap perilaku menolong memiliki hubungan yang signifikan.

Dari ketiga penelitian yang telah dijelaskan menunjukkan bahwa empati terbukti memiliki pengaruh terhadap perilaku prososial dalam berbagai kondisi serta pengukuran. Namun, hubungan empati terhadap perilaku prososial tidak selalu signifikan, hal ini salah satunya dikarenakan terdapat faktor usia partisipan yang mempengaruhi seseorang dalam bertindak prososial (Beadle, Sheehan, Dahlben \& Gutchess, 2013). Berbeda dengan penelitian yang dilakukan oleh Beadle, dkk. (2013) menguji peran usia dalam hubungan empati dan perilaku prososial. Partisipan dibagi atas dua kelompok usia yang berbeda, yaitu usia muda dan usia tua. Usia muda yang dimaksud adalah partisipan yang berada pada usia 18-26 tahun, sementara usia tua yang dimaksud adalah partisipan yang berada pada usia 67-93 tahun. Bahwa individu yang berada pada kategori usia muda memiliki skor empati emosional state yang lebih rendah dibandingkan individu yang berada di usia tua. Pengukuran empati kognitif trait juga dilakukan dan hasilnya diketahui bahwa individu yang berada di usia tua memiliki skor empati kognitif yang lebih tinggi dibandingkan dengan individu di usia muda. Sesuai dugaan, individu yang memiliki skor lebih tinggi di empati kognitif trait terkait dengan tingkat prososial yang ditunjukkan.

Peneliti melihat adanya perbedaan empati pada kategori usia dalam penelitian Beadle, dkk. (2013). Berdasarkan penelitian tersebut dapat diambil kesimpulan bahwa adanya perbedaan empati yang dimiliki oleh individu dengan adanya perbedaan usia, yaitu semakin bertambahnya usia individu empati yang dimiliki akan lebih tinggi baik secara kognitif maupun emosional. Studi lain milik Eisenberg dan Lennon (1983) menguji empati pada perbedaan jenis kelamin. Eisenberg dan Lennon (1983) menemukan bahwa terdapat perbedaan pada jenis kelamin dan empati ketika empati dinilai menggunakan indeks kuesioner (self-report). Hasilnya dilaporkan bahwa perempuan bereaksi dengan cara yang sesuai dengan peran feminin secara emosional, sedangkan laki-laki dilaporkan bereaksi dengan cara yang sesuai dengan peran maskulin dan menunjukan tindakan kurang responsif secara emosional.

Penelitian lainnya dilakukan oleh O’Brien, Konrath, Grühn, \& Hagen (2013) yang ternyata menemukan hasil yang sama dengan penelitian milik Eisenberg dan Lennon (1983) bahwa ketika trait empati diukur didapatkan hasil bahwa perempuan dilaporkan memiliki skor empati yang tinggi dibandingkan dengan laki-laki dalam memunculkan tingkah laku prososial. Studi longitudinal dengan perbedaan waktu selama satu tahun pengukuran dilakukan oleh Mestre, Samper, Frías dan Tur (2009) dengan menggunakan partisipan 
penelitian yakni remaja perempuan dan laki-laki usia antara 13 dan 16 tahun. Pada penelitian tersebut diketahui bahwa perempuan memiliki skor lebih tinggi pada trait empati saat diukur dengan menggunakan alat ukur IRI (Interpersonal Reactivity Index) jika dibandingkan dengan laki-laki.

Berbeda dengan penelitian yang dilakukan oleh Mestre, dkk (2009), penelitian yang dilakukan oleh McMahon, Wernsman dan Parnes (2006) pada remaja Afrika Amerika yang berjumlah 150 partisipan memberikan hasil yang berbeda, dikemukakan bahwa laki-laki terbukti memiliki skor empati lebih tinggi sehingga mereka juga cenderung memiliki skor yang tinggi pada pengukuran perilaku prososial. Beberapa penelitian menunjukkan bahwa perbedaan jenis kelamin sesuai dengan pola stereotip yang dimiliki, di mana perempuan cenderung menunjukkan jenis perilaku bantuan relasional yang lebih besar (misalnya memberikan kenyamanan), dibandingkan dengan laki-laki yang menunjukkan jenis perilaku prososial yang lebih instrumental (misalnya membantu pekerjaan rumah seseorang) (Eisenberg, Matin \& Fabes, dalam McMahon dkk., 2006). McMahon dkk. (2006) menjelaskan bahwa hasil tersebut sangat mungkin dipengaruhi oleh faktor lain seperti hubungan individu dengan lingkungan sosial, atau dalam lingkup lebih kecilnya adalah adanya kelompok belajar.

Dari adanya perbedaan hasil pada studi-studi penelitian sebelumnya, Bekkers (2010) menjelaskan analisis terhadap perilaku menolong yang memperlihatkan bahwa perempuan dengan usia muda memiliki sifat lebih extrovert, hangat, penolong, dan lebih baik dalam melihat perspektif dari orang lain dan lebih berempati untuk menunjukkan perilaku prososial. He, Inman, dan Mittal (2008) menemukan bahwa perilaku orang-orang dengan identitas jenis kelamin feminin konsisten dengan orientasi komunal yang menekankan pada fokus hubungan sosial, interpersonal affiliation dan memiliki hubungan yang harmonis, sedangkan identitas jenis kelamin maskulin konsisten dengan orientasi agentik yang berfokus pada perilaku asertif, fokus pada diri dan self-efficacy.

Sesuai dengan apa yang telah dijelaskan sebelumnya dapat diambil kesimpulan bahwa jenis kelamin juga memiliki pengaruh terhadap empati dan memiliki pengaruh terhadap perilaku prososial. Penelitian kali ini bertujuan untuk memperjelas peran jenis kelamin dalam memoderasi hubungan empati terhadap perilaku prososial dengan melakukan studi lanjutan terhadap studi yang telah dilakukan sebelumnya oleh Sze, dkk. (2012), Beadle, dkk. (2013), dan O'Brien, dkk. (2013). Pengukuran empati pada penelitian ini terfokus pada pengaruh empati emosional sebagai state terhadap perilaku prososial. Pada penelitian ini, peneliti ingin melihat interaksi jenis kelamin terhadap empati dan perilaku prososial. Induksi empati yang digunakan pada penelitian ini pun bertujuan untuk meningkatkan skor empati dengan memberikan tayangan video berupa kisah yang sedih. Sementara penelitian sebelumnya cara untuk meningkatkan empati menggunakan pemaparan musik dengan lirik prososial (Greitemeyer \& Osswald, 2010) dan pemberian tayangan film dengan tema "uplifting" atau "distressing" (Sze, dkk., 2012).

Empati seseorang dapat berkembang jika dipengaruhi oleh beberapa faktor seperti mood dan feeling yang akan mempengaruhi sebuah respon yang muncul ketika berinteraksi dengan orang lain (Hoffman, 2000), respon empati yang muncul juga akan berbeda jika dihadapkan pada situasi atau tempat tertentu (Hoffman, 2000). Sesuai dengan studi sebelumnya mengatakan bahwa empati tinggi atau rendah dapat muncul dari perbedaan usia seseorang dan jenis kelamin. Usia dapat mempengaruhi respon empati seseorang karena dengan bertambahnya usia maka kemampuan respon empati pun akan bertambah sesuai dengan bertambahnya pula pemahaman perspektif seseorang 
(Eisenberg \& Mussen, 1989). Empati menjadi faktor penting dalam memunculkan perilaku prososial, jika seseorang memiliki empati yang tinggi berarti ia telah dapat memahami keadaan yang dialami oleh orang lain sehingga dapat mendorong dirinya untuk bertindak prososial. Empati yang dimiliki tiap individu baik dengan jenis kelamin perempuan maupun laki-laki berbeda, seperti yang telah dipaparkan sebelumnya bahwa perempuan cenderung memiliki empati yang lebih tinggi dibandingkan dengan laki-laki. Perilaku prososial tidak terbatas pada siapa yang menolong dan kapan pertolongan tersebut diberikan. Perilaku prososial muncul pada diri individu yang memiliki empati tinggi, dan bersedia memberikan pertolongan secara sukarela tanpa mengharapkan manfaat secara langsung untuk dirinya.

Pada penelitian ini akan mengukur state empathy dan ingin membuktikan kembali apakah jika state diukur setelah menerima manipulasi untuk meningkatkan empati, bagaimana hasil dan hubungannya terhadap perilaku prososial. Pengukuran empati pada penelitian ini berfokus pada pengukuran empati emosional state yang dilihat pada perbedaan jenis kelamin. Berdasarkan adanya dipaparkan perbedaan hasil yang oleh penelitian sebelumnya, peneliti tertarik untuk meneliti apakah gender memiliki pengaruh dalam menguatkan atau melemahkan hubungan antara empati terhadap perilaku prososial.

Penelitian ini juga bertujuan untuk meneliti kembali pada kategori usia muda dengan dilakukannya induksi empati yang sama sebelum pengukuran empati dilakukan. Pada penelitian ini akan menjawab pertanyaan penelitian mengenai hubungan antara ketiga variabel penelitian, dan pengukuran perilaku prososial diukur dengan cara perilaku donasi. Terdapat dua hipotesis pada penelitian ini, yang pertama adalah terdapat pengaruh empati yang signifikan terhadap perilaku prososial. Kedua, jenis kelamin menguatkan atau melemahkan pengaruh empati terhadap perilaku prososial.

\section{Metode Penelitian}

Penelitian ini merupakan penelitian eksperimen laboratorium (laboratory experiment) dengan menggunakan desain faktorial 2 (Empati: netral vs empati) $\times 2$ (Jenis kelamin: laki-laki vs perempuan) between subject design. Between subject design menurut Gravetter dan Wallnau (2013) merupakan design penelitian yang menggunakan kelompok secara terpisah untuk setiap kondisi perlakuan, design ini digunakan untuk melihat apakah ada perbedaan secara signifikan antar kedua kelompok penelitian.

Partisipan dalam penelitian ini adalah individu dengan jenis kelamin perempuan dan laki-laki yang berada pada tahap perkembangan emerging adulthood yakni yang memiliki usia $18-25$ tahun. Pengambilan partisipan menggunakan teknik accidental sampling. Partisipan dijaring dengan menggunakan penyebara form dan partisipan dapat memilih waktu yang ada disesuaikan dengan ketersediaan waktu yang dimiliki partisipan. Dari penjaringan tersebut didapatkan jumlah partisipan pada penelitian ini sebanyak 126 mahasiswa Universitas Indonesia. Pada penelitian ini juga dilakukan pilot studi dengan tujuan untuk menguji alat tes, menguji metode pengambilan data serta menguji prosedur yang akan dilaksanakan. Namun pada penelitian ini, sebelum pilot studi dilakukan terlebih dahulu studi pendahulu (preliminary study).

Preliminary study dilakukan untuk menentukan video manipulasi yang akan digunakan. Video pertama diuji cobakan kepada 30 partisipan yang dibagi dalam dua kelompok (empati vs netral), situasi yang digunakan saat uji coba disamakan dengan situasi pada saat pelaksanaan penelitian yakni di kelas yang berbeda (kelas $A$, dan kelas $B$ ) dengan masingmasing 15 orang di setiap ruangan, jarak antar meja partisipan pun telah disesuaikan. Video pertama yang digunakan yakni video berupa kejadian alam yaitu longsor di Ponorogo bulan april 2017, terlihat jelas dalam video itu bagaimana tanah 
bergerak turun dan terjadi sebuah gempa susulan yang membuat warga panik dan durasi video tersebut selama empat menit. Setelah partisipan melihat video tersebut, partisipan diberikan alat ukur PANAS untuk melihat empati yang dimiliki, dan didapatkan hasil pada kelompok empati $(M=33,27 ; S D=6,273)$, sementara pada kelompok netral didapatkan hasil $(M=31,07 ; S D=4,044)$. Berdasarkan hasil tersebut diketahui mean pada dua kelompok memiliki hanya sedikit perbedaan, dan memiliki hasil yang tidak signifikan ( $p>$ 0,05).

Dari hasil tersebut, maka dilakukanlah preliminary study kedua dengan mengganti video untuk menginduksi empati yakni dengan menggunakan video yang berasal dari negara Thailand dengan durasi yang sama kurang lebih empat menit. Video tersebut menceritakan seorang gadis yang memiliki ayah dengan kekurangan berupa tunawicara. Gadis tersebut merasa marah dengan keadaan ayahnya, karena setiap hari di sekolah anak tersebut selalu di rundung oleh teman-temannya. Sampai suatu ketika ia memutuskan untuk mencoba bunuh diri dan ayahnya menolong putrinya dengan cara melakukan transfusi darah agar anaknya dapat selamat. Tiga puluh orang partisipan yang berbeda mengikuti preliminary study kedua dan didapatkan hasil bahwa kelompok empati sebesar $(M=31,47 ; S D=4,257)$, sementara pada kelompok netral didapatkan hasil sebesar $(M=31,07 ; S D=4,044)$. Dari hasil tersebut diketahui bahwa manipulasi pada dua kelompok eksperimen tidak memiliki perbedaan yang signifikan $(p>$ 0,05).

Dari kedua preliminary study yang dilakukan dapat disimpulkan bahwa videovideo tersebut kurang menggambarkan adanya perbedaan empati pada kelompok eksperimen (empati vs netral). Maka dari itu, peneliti mencoba untuk mengganti lagi video yang akan digunakan sebagai alat manipulasi dan video yang digunakan adalah video iklan bank BRI. Video tersebut bercerita mengenai seorang anak kecil laki-laki yang hanya tinggal bersama dengan ayahnya. Anak tersebut sangat merindukan kehadiran ibunya, namun ibunya telah nama meninggal dunia. Sampai suatu ketika ayahnya melihat bukti kerinduan anaknya pada saat malam hari anaknya tidur di lantai, dan di lantai tersebut ia mencoba untuk memeluk gambar ibunya yang ia buat sendiri. Setelah itu sang anak tersebut mencoba untuk terus membuat surat dan pada suatu hari ia membeli banyak balon. Balon tersebut ia gunakan untuk menyampaikan semua surat yang ia tulis pada ibunya di surga. Pada video ini, peneliti tidak melakukan pengukuran kepada partisipan, dan hanya bertanya secara verbal; "apa yang Anda rasakan setelah menonton video tersebut?" "dari skala 1-5 seberapa besar Anda merasakan hal tersebut?" "Menurut Anda, apakah video tersebut dapat memunculkan rasa empati seseorang?". Dari ketiga pertanyaan manipulasi tersebut yang diberikan kepada lima orang partisipan, semua partisipan menjawab bahwa video tersebut sesuai digunakan untuk memunculkan empati, dan kelima partisipan merasa sedih dengan cerita yang terdapat dalam video tersebut, karena video dengan cerita tersebut sangat erat dalam kehidupan sehari-hari yang berasal dari lingkungan sosial, dan video tersebut menjadi kuat pengaruhnya karena model dalam video tersebut adalah seorang anak kecil dan latar belakang kejadiannya di Indonesia. Maka dengan hasil yang telah didapatkan, peneliti memutuskan untuk menggunakan video ketiga untuk menginduksi empati partisipan.

Uji coba alat ukur. Uji coba alat ukur dilakukan kepada 20 partisipan mahasiswa (10 laki-laki dan 10 perempuan) Fakultas Psikologi dari berbagai angkatan. Pada tahap uji coba alat ukur, uji reliabilitas dilakukan. Uji reliabilitas dilakukan menggunakan Cronbach's alpha. Batas koefisien reliabilitas yang baik harus memiliki nilai cronbach's alpha sebesar 0,70-0,80 (Kaplan \& Sacuzzo, 
2005). Pada pilot studi ini didapatkan hasil uji reliabitas sebagai berikut:

Tabel 1 Reliabilitas instrumen pada pilot studi

\begin{tabular}{lll}
\hline Instrumen & Dimensi & $\begin{array}{c}\text { Reliabilitas } \\
(\boldsymbol{\alpha})\end{array}$ \\
\hline PANAS & Afek Positif & 0,734 \\
& Afek Negatif & 0,923 \\
\hline
\end{tabular}

Mengacu pada tabel 1, alat ukur PANAS dapat digunakan karena telah memenuhi standar yang baik menurut Nunnally dan Bernstein (1964) karena berada di atas 0,70.

Sebelum nantinya dilakukan uji hipotesis terlebih dahulu pada penelitian ini juga dilakukan uji reliabilitas studi utama pada instrumen PANAS, uji reliabilitas dalam penelitian ini menggunakan jumlah sampel yang lebih besar $(n=126)$. Hasil pengujian pada studi utama ini dapat dilihat pada tabel 2.

Hasil pengujian reliabilitas alat ukur PANAS tergolong baik dengan nilai Cronbach's Alpha sebesar 0,835. Pada masing-masing dimensi, untuk dimensi positif afek nilai Cronbach's Alpha sebesar 0,913.

Tabel 2. Reliabilitas instrumen pada studi utama

\begin{tabular}{lll}
\hline Instrumen & Dimensi & $\begin{array}{l}\text { Reliabilitas } \\
(\mathbf{\alpha})\end{array}$ \\
\hline PANAS & Afek Positif & 0,858 \\
& Afek Negatif & 0,913 \\
\hline
\end{tabular}

Prosedur. Penelitian ini menggunakan metode class setting di ruangan-ruangan yang telah disiapkan. Pembagian kelompok partisipan dilakukan dengan cara randomisasi, menghitung angka satu dan dua, partisipan yang mendapat angka satu ditempatkan di ruangan A (induksi empati), dan partisipan yang mendapat angka dua ditempatkan di ruangan $B$ (netral). Sebelum partisipan diberikan video, partisipan akan mengisi alat ukur PANAS yang diadministrasikan dua kali yakni pre-test dan post-test yang akan diisi setelah partisipan menonton video yang diberikan. Setelah partisipan mengisi post-test PANAS, partisipan akan melakukan pengukuran tingkat perilaku prososial, dengan diberikannya skenario di mana partisipan diminta untuk membayangkan suatu kejadian dan pengukuran prososial diukur berdasarkan donasi yang diberikan oleh partisipan. Donasi yang diberikan oleh partisipan menggunakan kupon uang yang telah disediakan oleh peneliti di dalam amplop, dan jika partisipan ingin memberikan donasi maka partisipan dipersilahkan untuk memasukan kupon uang tersebut ke dalam amplop kosong yang telah disediakan.

Pada penelitian ini metode atau teknik statistik yang digunakan untuk pengolahan data menggunakan teknik analisis deskriptif untuk memeroleh perhitungan mean dan standar deviasi tiap variabel. Analisis korelasi pearson digunakan untuk melihat hubungan antar variabel dalam penelitian. Selanjutnya menggunakan analisis Independent Sample T-test dan analisis ANOVA dalam perhitungan manipulation check. Independent sample t-test digunakan untuk untuk mengetahui apakah terdapat perbedaan rata-rata antara dua kelompok sampel, data yang digunakan biasanya berskala interval atau rasio (Gravetter \& Wallnau, 2013). Analisis ANOVA merupakan analisis statistik yang dapat menguji perbedaan antar kelompok dan dapat melihat apakah terdapat perbedaan makna antar perlakuan yang diberikan (Gravetter \& Wallnau, 2013).

\section{Hasil Penelitian}

Analisis menggunakan independent sample t-test digunakan untuk tiga hal. Pertama, analisis independent sample $t$ test yang digunakan untuk menguji manipulasi.

Hasilnya menunjukkan bahwa terdapat perbedaan nilai rata-rata afek positif yang signifikan antara kelompok eksperimen $(M=31,51 ; S D=6,841)$ dan kelompok kontrol $(M=27,70 ; S D=5,290)$. Maka dari itu, hasil 
Tabel 3. Hasil Independent sample t-test untuk cek manipulasi studi utama pengukuran PANAS

\begin{tabular}{lllcccc}
\hline Instrumen & Dimensi & Kelompok (N) & Mean & SD & t-statistik & p-value \\
\hline PANAS & Afek Positif & Empati (63) & 31,51 & 6,841 & 3,496 & $\mathrm{p}<0,05$ \\
& & Netral (63) & 27,70 & 5,290 & 3,496 & $\mathrm{p}<0,05$ \\
\hline
\end{tabular}

Tabel 4. Hasil Independent sample t-test PANAS pada kelompok empati

\begin{tabular}{lllccc}
\hline Kelompok (N) & Dimensi & Mean & SD & t-statistik & p-value \\
\hline Empati (63) & Afek Positif & 31,51 & 6,841 & 3,496 & $\mathrm{p}<0,05$ \\
& Afek Negatif & 24,87 & 6,847 & 2,965 & $\mathrm{p}<0,05$ \\
\hline
\end{tabular}

Tabel 5. Hasil Independent sample t-test pengukuran donasi

\begin{tabular}{llcccc}
\hline Variabel & Kelompok (N) & Mean & SD & t-statistik & p-value \\
\hline DONASI & Empati (63) & 83.809 & 22.028 & 2,377 & $\mathrm{p}<0,05$ \\
& Netral (63) & 72.698 & 29.849 & 2,377 & $\mathrm{p}<0,05$ \\
\hline
\end{tabular}

Tabel 6. Hasil main effect dan efek interaksi dari empati dan jenis kelamin terhadap perilaku prososial (donasi) dengan menggunakan ANOVA.

\begin{tabular}{clcccc}
\hline $\begin{array}{c}\text { Variabel } \\
\text { Terikat }\end{array}$ & \multicolumn{1}{c}{ Sumber } & df & F & Sig. & $\begin{array}{c}\text { Partial Eta } \\
\text { Squared }\end{array}$ \\
\hline Donasi & Kelompok Eksperimen (A) & 1 & 3,825 & 0,053 & 0,030 \\
& Gender (B) & 1 & 0,010 & 0,920 & 0,000 \\
& A x B & 1 & 0,452 & 0,503 & 0,004 \\
& USIA $^{*}$ & 1 & 14,375 & 0,000 & 0,106 \\
\hline $\mathrm{R}^{2}=0,132 ;\left(^{*}\right) \mathrm{p}<0,05$ & & & & \\
\hline
\end{tabular}

menunjukkan bahwa secara signifikan manipulasi terbukti dapat meningkatkan empati pada kelompok eksperimen.

Kedua, analisis independent sample t-test digunakan untuk melihat skor afek yang dimiliki individu yang termasuk kedalam kelompok empati.

Hasilnya menunjukkan bahwa terdapat perbedaan nilai rata-rata kelompok eksperimen yang signifikan antara afek positif $(M=31,51 ; S D=6,841)$ dan afek negatif $(M=24,87 ; S D=6,847)$. Temuan ini mendorong rasionalisasi pembahasan mengenai empati emosional bahwa empati emosional memiliki nilai yang lebih tinggi pada dimensi afek positif dibandingkan dengan nilai pada dimensi afek negatif.

Ketiga, analisis independent sample t-test digunakan untuk pengukuran donasi.

Hasilnya menunjukkan kelompok empati memiliki nilai rata-rata yang lebih tinggi terhadap pemberian donasi $(M=83.809$; $S D=22.028$ ) dibandingkan dengan kelompok netral $(M=72.698 ; \quad S D=29.849) \quad$ secara signifikan. Berdasarkan ketiga analisis menggunakan independent sample t-test 
dapat diambil kesimpulan bahwa individu yang termasuk ke dalam kelompok eksperimen memiliki nilai empati emosional yang lebih tinggi. Empati emosional yang dimiliki terbukti dapat lebih meningkatkan perilaku prososial dalam hal ini memberikan sumbangan, yang dilihat berdasarkan nilai afek positif yang dimiliki.

Analisis utama yang dilakukan pada penelitian ini menggunakan analisis Twoway Analysis of Variance (ANOVA). ANOVA digunakan untuk mendapatkan hasil uji hipotesis dan mengetahui perbandingan mean atau main effect dari variabel bebas empati (video netral vs. video empati) dan interaksi antara kelompok eksperimen dan gender terhadap variabel terikat perilaku prososial (donasi). Berikut tabel hasil perhitungan menggunakan ANOVA.

ANOVA dilakukan untuk menguji perbedaan mean antara kelompok partisipan yang memiliki tingkat empati tinggi dan kelompok partisipan yang memiliki tingkat empati rendah. Berdasarkan tabel 6 . diketahui secara signifikan kelompok eksperimen memiliki efek yang cukup signifikan terhadap perilaku donasi $(F(1)=$ $3,825, p=0,053)$. Variabel usia ikut disertakan dalam pengolahan sebagai variabel covariate. Analisis menunjukkan bahwa usia mempengaruhi individu pada perilaku prososial secara signifikan $(F(1)=14,375$, $p<0,001)$. Oleh karena itu dapat diambil kesimpulan bahwa donasi tidak dipengaruhi oleh jenis kelamin dan empati emosi emosional pada individu, namun dapat dipengaruhi oleh variabel usia.

\section{Diskusi}

Hasil dari penelitian ini menunjukkan bahwa ada pengaruh hubungan antara empati dan perilaku prososial, pengaruh tersebut bersifat positif. Hal ini berarti, secara signifikan individu yang memiliki skor empati emosional yang tinggi memiliki tingkat perilaku prososial yang juga tinggi, temuan ini sejalan dengan penelitian sebelumnya yang dilakukan oleh Eisenberg (1991); Beadle, dkk. (2013), Sze, dkk. (2012). Analisa moderasi yang dilakukan dalam penelitian ini menemukan bukti bahwa jenis kelamin tidak memiliki efek yang signifikan terhadap pengaruh empati terhadap perilaku prososial.

Penelitian ini mendapatkan temuan terbaru dan mendapatkan hasil yang berbeda dengan penelitian yang dilakukan oleh Mestre, dkk. (2009), dan McMahon, dkk. (2006). Kedua penelitian tersebut memaparkan hasil bahwa dalam perbedaan sampel penelitian, perempuan terbukti memiliki skor perilaku prososial yang lebih tinggi (Mestre, dkk., 2009), dan lakilaki terbukti memiliki skor perilaku prososial yang lebih tinggi (McMahon dkk., 2006). Pada penelitian ini tidak dapat dilihat skor empati mana yang lebih tinggi diantara perempuan dan laki-laki. Namun, hanya dapat diketahui bahwa skor positif empati memiliki hasil yang signifikan $(p<0,05)$ pada jenis kelamin. Pada penelitian ini juga ditemukan tidak adanya interaksi jenis kelamin pada empati terhadap perilaku prososial. Skor perilaku prososial yang dihasilkan tidak jauh berbeda di dua kelompok eksperimen, hal ini dapat mengacu pada stereotip yang diberikan pada perempuan dan laki-laki, telah dipaparkan sebelumnya bahwa perempuan akan bereaksi sesuai dengan peran yang dimiliki yakni bersifat feminin secara emosional sehingga jika perempuan memiliki empati yang tinggi maka dengan kata lain tingkah laku prososial yang tinggi akan dimunculkan oleh perempuan dibandingkan dengan laki-laki (Eisenberg \& Lennon, 1983; O'Brien dkk., 2013). Selain adanya stereotip pada perbedaan jenis kelamin, peneliti menduga hasil yang didapatkan tidak berbeda jauh dikarenakan adanya perbedaan proporsi antara laki-laki dan perempuan yang menjadi sample penelitian, sehingga hasil yang didapatkan tidak memiliki interaksi yang signifikan. Hasil tersebut merupakan kelemahan dari penelitian ini, karena pada saat pelaksaan penelitian, peneliti tidak melakukan kontrol secara ketat untuk membuat sampel penelitian yang melibatkan antara laki-laki dan perempuan 
menjadi sama jumlahnya. Selain itu, hubungan antara empati dan perilaku prososial juga bisa dipengaruhi faktor lainnya selain dari jenis kelamin, seperti melihat kematangan emosi pada diri individu. Penelitian yang dilakukan oleh Asih dan Pratiwi (2010) menemukan hasil lain, bahwa terdapat hubungan yang positif signifikan antara empati, kematangan emosi, jenis kelamin terhadap perilaku prososial. Kematangan emosi terhadap perilaku prososial $\mathrm{rxy}=0,794$ dan $\mathrm{p}=$ 0,000 . Kematangan emosi diartikan sebagai kemampuan individu dalam memberikan respon emosi dengan baik dalam menghadapi sebuah tantangan serta mampu untuk menyelesaikannya (Asih \& Pratiwi, 2010).

Berdasarkan hasil yang telah dipaparkan sebelumnya, didapatkan hasil bahwa empati emosional lebih dipengaruhi oleh afek positif dibandingkan dengan afek negatif, karena afek positif lebih berpengaruh terhadap munculnya perilaku prososial. Hasil tersebut sesuai dengan penelitian yang dilakukan oleh Aknin, dkk. (2012) yang menyebutkan bahwa afek positif lebih berperan dalam memunculkan perilaku prososial. Selanjutnya, hasil yang didapatkan dari skor rata-rata yang dimiliki oleh variabel prososial yaitu donasi memiliki perbedaan yang kecil antara kelompok empati dan kelompok netral. Perbedaan yang kecil tersebut dapat diasumsikan dari adanya pemberian pengukuran perilaku prososial yang menggunakan kupon memiliki nominal kecil. Karena $3 / 4$ partisipan di kelompok empati memberikan semua kupon yang dimiliki untuk disumbangkan. Penelitian selanjutnya dapat mereplikasi studi ini dengan cara memperbesar nominal yang diberikan kepada partisipan untuk dilihat pengaruhnya terhadap perilaku prososial.

\section{Kesimpulan}

Mengacu pada hasil dan analisa dari penelitian ini, sebagaimana telah dijelaskan sebelumnya, terdapat beberapa hal yang dapat disimpulkan. Menjawab pada pertanyaan penelitian pertama yang sudah dirumuskan, hipotesis satu penelitian dapat diterima dan terbukti secara signifikan bahwa empati mempengaruhi munculnya perilaku prososial. Pengaruh empati terhadap perilaku prososial terbukti meningkatkan empati emosional yang lebih tinggi di kelompok eksperimen dibandingkan empati di kelompok netral pada dimensi afek positif. Hasil tersebut menunjukkan bahwa empati emosional dan donasi lebih besar dipengaruhi oleh skor afek positif. Kemudian, menjawab pertanyaan penelitian kedua, hipotesis kedua dalam penelitian ini ditolak. Didapatkan analisa moderasi yang dilakukan memperlihatkan bahwa tidak terdapat efek moderasi jenis kelamin yang dihasilkan pada pengaruh empati terhadap perilaku prososial.

Penulis dapat mengajukan beberapa saran, untuk dilakukannya penelitian lanjutan terkait topik ini. Berikut saransaran yang dapat diajukan oleh penulis terkait penelitian yang akan dilakukan kedepannya. Dalam melakukan penjaringan partisipan perlu dilakukan secara ketat sehingga dalam mendapatkan partisipan akan memiliki proprosi yang seimbang antar kelompok atau antar jenis kelamin.

Manipulasi yang dilakukan perlu untuk diperketat pada dua kelompok manipulasi, agar terdapat perbedaan secara signifikan dari empati emosional pada dua kelompok penelitian. Skor perilaku prososial yang dihasilkan tidak beda jauh di dua kelompok eksperimen, karena pemberian kupon bisa diasumsikan kecil, karena $3 / 4$ dari total partisipan memberikan semua kupon yang dimiliki untuk donasi. Pada kelompok netral hanya memiliki perbedaan yang sedikit dari donasi yang diberikan. Jika kupon atau nilai uang yang diberikan dinaikan nominalnya, peneliti menduga mungkin akan didapatkan hasil dengan perbedaan yang signifikan diantara dua kelompok eksperimen. Penelitian selanjutnya perlu untuk memasukkan variabel jenis kelamin, dua kategori usia dan mencari 
variabel lain seperti kematangan emosi. Sehingga dapat ditemukan hasil yang benar-benar dapat menjawab variabel apa saja yang lebih mempengaruhi empati terhadap perilaku prososial.

\section{Daftar Pustaka}

Aknin, L. B., Dunn, E. W., \& Norton, M. I. (2012). Happiness runs in a circular motion: Evidence for a positive feedback loop between prosocial spending and happiness. Journal of Happiness Studies, 13(2), 347-355. doi:10.1007/s10902-011-9267-5

Asih, G.Y., \& Pratiwi, M. M. S. (2010) Perilaku prososial ditinjau dari empati dan kematangan emosi. Jurnal Psikologi Universitas Muria Kudus, 1(1), 33-42. Retreived from http://docshare01.docshare.tips/files /19514/195149594.pdf\#page=35

Baron, R. A., Branscome, N. R., \& Byrne, D. (2008). Social psychology. Boston: Pearson Allyn and Bacon.

Baron, R. A. \& Byrne, D. (1994). Social psychology. Understanding human interaction. Seventh Edition

Batson, C. D. (1991). The altruism question: Towards a social psychology answer. New Jersey: Erlbaum

Beadle, J. N., Sheehan, A. H., Dahlben, B., \& Gutchess, A. H. (2013). Aging, empathy, and prosociality. The Journals of Gerontology: Series B: Psychological Sciences and Social Sciences, doi:10.1093/geronb/gbt091

Bekkers, R. (2010). Who gives what and when? A scenario study of intentions to give time and money. Social Science Research, 39(3), 369-381. doi: 10.1016/j.ssresearch.2009.08.008

Cialdini, R. B., Brown, S. L., Lewis, B. P., Luce, C., \& Neuberg, S. L. (1997). Reinterpreting the empathy-altruism relationship: When one into one equals oneness. Journal of personality and social psychology, 73(3), 481494 doi:10.1.1.473.5871
Davis, H. M. (1983). Measuring individual differences in empathy: Evidence for multidimensional approach. Journal of Personality and Social Psychology, 44 (5), 113-126. doi: 0022$3514 / 83 / 4401$

Eisenberg, N. (1991). Meta-analytic contributions to the literature on prosocial behavior. Personality and Social Psychology Bulletin, 17(3), 273-282.

Eisenberg, N., \& Lennon, R. (1983). Sex differences in empathy and related capacities. Psychological Bulletin, 94(1), 100-131. doi: 10.1037/00332909.94.1.100

Eisenberg, N., \& Mussen, P. H. (1989). The roots of prosocial behavior in children $4^{\text {th }}$ Ed. UK: Cambridge, University Press.

Gravetter, F. J., \& Wallnau, L. B. (2013). Statistics for the Behavioral Sciences. Ninth Edition. Wadsworth, Cengage Learnig.

Greitemeyer, T., \& Osswald, S. (2010). Effects of prosocial video games on prosocial behavior.Journal of personality and social psychology, 98(2), 211221. doi: $10.1037 / a 0016997$.

He, X., Inman, J. J., \& Mittal, V. (2008), "Gender Jeopardy in Financial Risk Taking," Journal of Marketing Research, 45(4), 414-424. doi: 10.1509/jmkr.45.4.414

Hoffman, M. L. (2000). Empathy and Moral Development. Cambridge: Cambridge University Press.

Kaplan, R. M., \& Sacuzzo, D. P. (2005). Psychological testing: Principles, applications, and issue. Belmont: Thomson Wadsworth.

McMahon, S. D., Wernsman, J., \& Parnes, A. L. (2006). Understanding prosocial behavior: The impact of empathy and gender among African American adolescents. Journal of Adolescent Health, 39(1), 135-137. doi:10.1016/j.jadohealth.2005.10.008

Mestre, M. V., Samper, P., Frías, M. D., \& Tur, A. M. (2009). Are women more empathetic than men? A longitudinal 
study in adolescence. The Spanish journal of psychology, 12(01), 76-83. doi: $10.1017 / S 1138741600001499$

Nunnally, J. C., \& Bernstein, I. H. (1994). Psychometric Theory (3rd ed.). New York: McGraw-Hill.

O'Brien, E., Konrath, S. H., Grühn, D., \& Hagen, A. L. (2013). Empathic concern and perspective taking: Linear and quadratic effects of age across the adult life span. The Journals of Gerontology Series B: Psychological Sciences and Social Sciences, 68(2), 168-175. doi: 10.1093/geronb/gbs055

Rogers, K., Dziobek, I., Hassenstab, J., Wolf, O. T., \& Convit, A. (2007). Who cares? Revisiting empathy in Asperger syndrome. Journal of autism and developmental disorders, 37(4), 709-715. doi: 10.1007/s10803-0060197-8

Schroeder, D. A., \& Graziano, W. G. (2015). The Oxford handbook of prosocial behavior. Oxford University Press, USA.

Stürmer, S., Snyder, M., Kropp, A., \& Siem, B. (2006). Empathy-motivated helping: The moderating role of group membership. Personality and Social Psychology Bulletin, 32(7), 943956. doi: 10.1177/0146167206287363

Sze, J. A., Gyurak, A., Goodkind, M. S., \& Levenson, R. W. (2012). Greater emotional empathy and prosocial behavior in late life. Emotion, 12, 1129-1140. doi:10.1037/a0025011

Watson, D., Clark, L. A., \& Tellegen, A. (1988). Development and validation of brief measures of positive and negative affect: The PANAS Scales. Journal of Personality and Social Psychology, 54(6), 1063-1070. doi: 10.1037/0022-3514.54.6.1063 